\title{
Improve Mathematical Connections Skills with Realistic Mathematics Education Based Learning
}

\author{
Hotmaria Menanti \\ Department of Mathematics, Science \\ Faculty \\ Universitas Negeri Medan \\ Indonesia \\ hotmariamenanti@gmail.com
}

\author{
Bornok Sinaga \\ Department of Mathematics, Science \\ Faculty \\ Universitas Negeri Medan \\ Indonesia
}

\author{
Hasratuddin \\ Department of Mathematics, Science \\ Faculty \\ Universitas Negeri Medan \\ Indonesia
}

\begin{abstract}
The intention of the present study was to see the improvement of students' mathematical connections skills. Improving mathematical connections capabilities by developing Realistic Mathematics Education (RME) based learning tools. This research is a research development (research and development), the results of this product are the lesson plan, student activity sheet, the teachers' book guidance, and students' book. The development of learning device based on realistic approach developed by using 4-D development model from Thiagarajan. The result of this research shows: learning device which is developed is valid, both in the validity of the content and validity of construction, there is an increase in mathematical connection ability of students using the device developed learning, and learning tools developed meet the effective criteria, viewed from: a) mathematical connection ability of students fulfilled, b) ideal time of student activity fulfilled, c) achievement of teacher manage class fulfilled and d) student positive response.
\end{abstract}

Keywords: Development of learning Device, 4-D from Thiagarajan, Mathematical connection ability.

\section{INTRODUCTION}

Mathematical connection is one of the must-have capabilities to solve problems. According to NCTM (2000), mathematical connections are important part that should be emphasized at every level of education [1]. Hafiz, et al (2017) also said the ability of mathematical connections is one of the mathematical forces that must be developed in the learning of mathematics in schools [2]. The ability of a mathematical connection is required to relate to various ideas or mathematical ideas accepted by students (Fauzi: 2015) [3]. Siregar and Edy Surya (2017) also asserted, with the ability of mathematical connections, the ability of students' thinking in mathematics is expected to become more widespread. [4] In addition, the ability to Mathematical connection also can improve students' cognitive abilities such as recall, understand the application of environmental concepts and so on. Without applying the concept of student experience, it would be difficult to remember certain material and remember too many separate concepts whereas mathematics is rich in principles. Mathematical connections are interrelationships between mathematical topics, interrelationships between mathematics and other disciplines, and mathematical relation to the real world or in everyday life. In addition, Coxford (1995) mathematical connection ability is the ability to connect conceptual and procedural knowledge, using mathematics on other topics, using mathematics in life activities, using intertopic connections in mathematics [5]. The facts show that students' Mathematical connection ability is still low. The low level of student's Mathematical connection ability is seen from the diagnostic test result in the form of story for prerequisite material given to 35 students. The test results show students who are able to connect between mathematical concepts, namely: to link previous mathematical knowledge with newly taught concepts is $31.42 \%$, Students who are able to connect the concept of mathematics with other fields of science, namely: to connect mathematical concepts with other fields of science is $25.7 \%$, students are able to connect the concept of mathematics with everyday life, namely: linking the concept of mathematics with daily life is $37.1 \%$. One of the causes of mathematical connection ability of low students is the teacher difficulty in arranging learning devices that direct and train students to have the ability mathematical connections. Based on the results of interviews to teachers in the field of mathematics studies, during this mathematical connection ability does not become a focus in learning activities. On the other hand, researchers found that no teacher has a learning tool that focuses on improving students' mathematical connection ability.

Haggarty and Keynes (in Muchayat 2011) outline In order to improve the teaching and learning of mathematics in the classroom, it is necessary to improve the understanding of teachers, students, materials used for learning and interaction between them. In the implementation of learning, learning tools play an important role in the learning process [6]. Sanjaya (2010) states that "through a mature and accurate planning process, teachers are able to predict correctly the success that will be achieved, in addition to the learning process will be directed and organized, and teachers can use the time as effective as possible to get the successful learning process [7]. 
The lack of mathematical connection ability when learning mathematics is caused by many things, one of which is because students are not able to connect the math ideas that have been taught and newly taught mathematical ideas. This happens because students may often memorize mathematical ideas without trying to interpret the idea (Hafiz, et al: 2017) [1]. According to Ausubel, learning is said to be meaningful if the information learned by learners is prepared in the appropriate cognitive structure so that learners have a strong memory and transfer learning is easily achieved. In addition, Fauzi (2015) also said students should be given the opportunity to see this connection in learning mathematics [3]. The main purpose of the mathematical connection is emphasized to the students who play a major role in making the connection. In order for the learning objectives to achieve the expected targets, it is necessary to select the appropriate learning approach, and also need to develop the learning tools in accordance with the learning approach used. The learning approach should be able to make students active in learning activities, make learning meaningful, and able to improve students' mathematical connection ability.

Realistic approach is one solution to the above problem, because According to Web et all (2011) the principle of realistic approach is student involvement in mathematics must be started in a meaningful context [8]. The development of that understanding and the ability to create a sense of mathematical representation begins with the students' own formal reasoning. Then Kwon (2002) argues that the RME theory focuses on reinventing itself through mathematical processes as well as taking into account the strategy of informal and interpretation, through the problem of the context based on the real experience [9]. Realistic-based learning approaches can also improve students' mathematical connection ability. As the results of Sirait's research, et al (2017) show that the students' mathematical connection ability is increased by using realistic approach-based learning. Students are more enthusiastic about using a realistic approach-based learning approach [10].

Based on the problem that has been described, the purposes of this research are; 1) to develop a learning tool based on realistic mathematical approaches in order to improve the ability of mathematical connections; 2) to analyze the improvement of students 'Mathematical Connection capabilities using the tools of Realistic based learning that have been developed; 3) to develop realistic based mathematics learning tools that are effective in improving students' mathematical connection ability.

\section{LITERATURE REVIEW}

\section{A. Ability of Mathematical Connection}

According to Coxford (1995) the ability of mathematical connections is the ability to connect conceptual and procedural knowledge, using mathematics on other topics, using mathematics in life activities, using inter-topic connections in mathematics [5]. The National Council of Teachings of Mathematics (2000) suggests a mathematical connection is the interrelationship of topics mathematics, the interrelation between mathematics and other disciplines, and the relation of mathematics to the real world or in everyday life [1]. Gordah (2012) says mathematics consists of several branches and each branch is not closed which each stands alone, but a whole that united [11]. They can see mathematical relationships affecting each other between mathematical topics, in contexts that link mathematics with other subjects, as well as in their own interests and experiences (Madur: 2013) [12]. National Council of Teachers of Mathematics (2000) mathematical connections is an important part that should be emphasized at every level of education [1]. According to NCTM (2000) there are two general types of mathematical connections namely:[1]

- Modeling connections are the relationships between problem situations that arise in the real world or in other disciplines with their mathematical representation, whereas

- Mathematical connections are relations between two equivalent representations, and between the completion process of each representation.

For example: if a problem situation has modeling connections with algebraic and graphic equations, then the algebraic representation has a mathematical connection with a graphical representation. Mathematical connections also occur between the process of calculating algebra with graphical analysis that results in the same solution.

Based on the above explanation it can be concluded that mathematical connection is the ability of students to link the concepts of mathematics either between the concepts in mathematics itself or associate the concept of mathematics with concepts in other fields or with everyday life.

\section{B. Realistic Approach}

According to Heuvel-Panhuizen (2003) Realistic Mathematics Education (RME) is a theory of mathematics education with specific domain instructions [13]. HeuvelPanhuizen (2003) also asserted that the realistic word here comes from the Dutch language "zich realiseren" which means imagining, here more intended to offer problems imaginable by students rather than focusing on the world situation [13]. Realistic Mathematics Education (RME) is one approach to mathematics learning, which is oriented to the mathematization of daily experience and apply it in everyday life. Kwon (2002) argues that the RME theory focuses on reinventing the world through mathematical processes and takes into account the strategies of informal resolution and interpretation, through the problem of context based on real experience [9]. This RME concept can help students to improve their knowledge of mathematics. Because students are not only applying mathematical symbols or formulas, but also imagining the problems given, making students reasoning and connected with real life so as to solve existing problems and understand its benefits directly. According to Web et all (2011) the principle of RME is student involvement in mathematics must begin in a meaningful context [8]. The development of that understanding and the ability to create a sense of mathematical representation begins with the students' own formal reasoning. While Gravemeijer (1994) formulates three RME principles:[14]

-Guided Reinvention and Progressive

- Didactical phenomenology 


\section{- Self-developed models}

Based on the expert opinion above, the RME (Realistic Mathematics Educations) Approach is a teaching approach that starts from the real thing for the student (reality), or the real problem in the student environment and focuses on recreation with characteristic: (1) using the problem contextually, (2) using the model, (3) using student contributions, (4) interactive and (5) using intertwinment..

\section{RESEARCH METHODOLOGY}

This type of research is Research Development. The development model used is a 4-D development model from Thiagarajan which includes four stages: designing, designing, developing and disseminating

\section{A. Learning Device Development}

Learning tool developed in the form of Learning Implementation Plan (RPP), Teacher Handbook (BPG), Student Book (BS), Student Activity Sheet (LAS) and research instrument in the form of Test of Mathematical connection ability (TKKM). Device development is done by using 4-D development model from Thiagarajan which includes four stages: designing, designing, developing and disseminating.

\section{B. Instrument and Data Collection Techniques}

The instruments used in this study include instruments for assessing the validity and effectiveness of learning tools. Instruments used in the form of observation sheets, and tests.

\section{a.The Validity of Learning Devices Learning}

devices are said to be valid if they meet the criteria of content validity and construct validity. The validity of content is performed by 5 validators by assigning values 1 to 5 in each assessment column covering the following aspects: 1) format, 2) language, 3) content, and 4) illustrations. Furthermore the overall expert assessment is calculated average to obtain the criteria of content validity assessment as follows:

TABLE I CRITERIA FOR INVALIDITY RATE AND LEARNING TOOL

\begin{tabular}{c|l|l}
\hline No & $\boldsymbol{V a}$ & $\begin{array}{l}\text { Criteria } \\
\text { Kevalidan }\end{array}$ \\
\hline 1 & $1 \leq \mathrm{Va}<2$ & Invalid \\
\hline 2 & $2 \leq \mathrm{Va}<3$ & Less Valid \\
\hline 3 & $3 \leq \mathrm{Va}<4$ & Enough Valid \\
\hline 4 & $4 \leq \mathrm{Va}<5$ & Valid \\
\hline 5 & $\mathrm{Va}=5$ & Very Valid \\
\hline Information: & &
\end{tabular}

$\mathrm{Va}$ is the value of the determination of the validity level of the learning device.
Learning tool based Realistic approach meets the validity of the content that is expected if the average validator assessment of all learning devices are on valid criteria or very valid. If not met, then it needs to be revised. Thus so on to obtain learning devices that meet the validity of the contents.

Furthermore, the validity of the construct to test the ability of mathematical connections. Before being used for field trials, the grains of mathematical test maternity tests were tested outside the research subjects to measure the validity and reliability. To measure the validity of the item can use the formula product moment correlation (Arikunto 2012) follows:"

$$
r_{x y}=\frac{N \sum_{x y}-\left(\sum_{x}\right)\left(\sum_{y}\right)}{\sqrt{\left.\left\{N \sum x^{2}-\left(\sum x\right)^{2}\right\}_{N} \sum y^{2}-\left(\sum y\right)^{2}\right\}}}
$$

Information :

rxy: correlation coefficient between variables $\mathrm{x}$ and $\mathrm{y}$ $\Sigma x y$ : the number of multiplications between $\mathrm{x}$ and $\mathrm{y}$

$\mathrm{x}$ : score of item gained

$\mathrm{y}$ : total score

$\mathrm{N}$ : number of subjects

Furthermore, to calculate the reliability coefficient of test items used Alpha-Cronbach (Arikunto 2012) as follows:

$$
r_{11}=\left(\frac{k}{k-1}\right)\left(1-\frac{\sum \sigma_{b}^{2}}{\sum \sigma_{t}^{2}}\right)
$$

Information:

$$
\begin{array}{ll}
r_{11} & : \text { test reliability coefficient } \\
\mathrm{k} & : \text { number of questions } \\
\sum \sigma_{b}^{2} & : \text { the number of variance scores per test item. } \\
\sigma_{t}^{2} & : \text { total variance }
\end{array}
$$

\section{b. The Effectiveness of Learning Devices}

Learning device effectiveness is reviewed based on: 1) The mathematical connection ability of students is fulfilled, that is at least $80 \%$ of students who follow the learning got score 56 (maximum score 100). 2) Achievement of ideal time percentage of student and teacher activity determined. 3) Teachers' achievement of managing the class is at least good enough. 4) At least $80 \%$ of the number of subjects examined for each trial provided a positive response to the components and learning activities.

Student activity is reviewed based on the average observer's assessment of all meetings on each aspect of the activity observed. The criteria of effectiveness based on student activity is achieved if it meets the ideal time tolerance percentage defined (Sinaga 2007) [16].As the student activity criteria based on the achievement of the ideal time tolerance defined as following 
Table 4. Percentage of Ideal Time and Student Activity Tolerance Limit

\begin{tabular}{|c|c|c|c|}
\hline Student Activity Category & Ideal time & $\begin{array}{l}\text { Interval Teleransi } \\
\text { PWI }\end{array}$ & Ideal Criteria \\
\hline $\begin{array}{l}\text { Pay attention / listen to teacher / friend } \\
\text { explanations }\end{array}$ & $\begin{array}{l}25 \% \text { dan } \\
\text { WI }\end{array}$ & $\begin{array}{l}20 \% \leq \text { PWI } \leq 30 \\
\%\end{array}$ & \multirow{5}{*}{$\begin{array}{l}\text { Three from } 1 \text {, } \\
2,3,4,5 \text { meet, } \\
\text { and } 3,4 \text { must } \\
\text { meet }\end{array}$} \\
\hline $\begin{array}{l}\text { Reading student's books (BS) and } \\
\text { student activity sheets (LAS) }\end{array}$ & $\begin{array}{l}15 \% \text { dan } \\
\text { WI }\end{array}$ & $\begin{array}{l}10 \% \leq \text { PWI } \leq 20 \\
\%\end{array}$ & \\
\hline $\begin{array}{l}\text { Recording teacher explanations, taking } \\
\text { notes from books, solving LAS } \\
\text { problems, summanizing group wotk }\end{array}$ & $\begin{array}{l}30 \% \text { dan } \\
\text { WT }\end{array}$ & $\begin{array}{l}25 \% \leq \mathrm{PWI} \leq 35 \\
\%\end{array}$ & \\
\hline $\begin{array}{l}\text { Discuss / ask, propose ideas, between } \\
\text { students and friends or between } \\
\text { students and teachers, and davi } \\
\text { conclusions of a procedure or concept }\end{array}$ & $\begin{array}{l}30 \% \text { dan } \\
\text { WT }\end{array}$ & $\begin{array}{l}25 \% \leq \mathrm{PWI} \leq 35 \\
\%\end{array}$ & \\
\hline $\begin{array}{l}\text { Conduct behaviors that ate not reles ant } \\
\text { to leaming }\end{array}$ & $\begin{array}{l}0 \% \text { dani } \\
\text { WT }\end{array}$ & $0 \% \leq$ PWI $\leq 5 \%$ & \\
\hline
\end{tabular}

Information:

PWI is the ideal percentage of time

WT is the time available at each meeting.

Student response is reviewed based on students' answers to the given questionnaire. The criteria of effectiveness based on student responses are fulfilled if the classical $\geq 80 \%$ of subjects give a positive response (Sinaga 2007), ie to all aspects that are asked related to the device and the implementation of learning [16].

\section{c. Data Analysis To Know How To Improve The Ability Of Mathematical Connection}

Data analysis to find out how to improve the ability of normalized as follows:

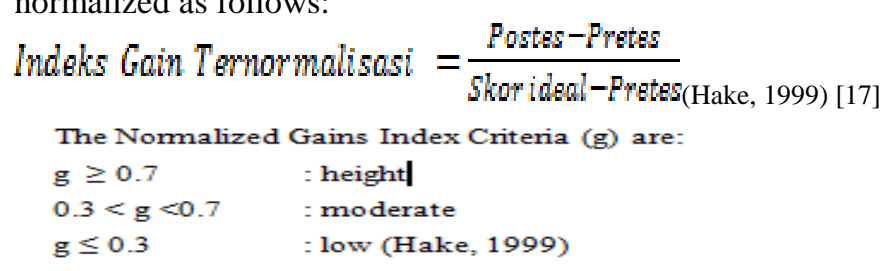

\section{RESUlTS AND DISCUSSION OF RESEARCH}

\section{A. Description of Learning Device Development Stage}

Development of learning tools has been completed using the 4-D development model from Thiagarajan with the following details:

\section{Description of Stage Definition (Define)}

Based on the results of observation and analysis of learning tools in junior high school, shows that during this time teachers do not have learning tools that can improve the ability of mathematical connections and creative thinking. To overcome these problems need to be developed learning tools based on realistic approach. By developing learning-based tools realistic approach, students are trained to link their knowledge that they have in solving the problems given. Thus the ability of students' mathematical connections can be increased. The learning tools are developed in the form of RPP, LAS, Teacher Book, Student Book and test result of learning in the form of math connection and thinking ability test creative students for SPLDV material (Two-variable Linear equation system)

\section{Description of Stage Definition (Define)}

To measure the ability of students in achieving learning objectives developed a tool of assessment of learning outcomes in the form of test of mathematical connection ability in the material system of two linear equations. Mathematical connection ability of students divided by 2, PreTest of ability mathematical connection consists of 4 items in the form of description and Post-Test consists of 7 questions in the form of description. While the creative thinking ability test consists of 3 questions for Pre-Test and Post-Test.

The learning media comprised of: Lesson Plan (RPP), Student Activity Sheet (LAS), Student Book (BS), Master Book (BG), as well as tests of students' mathematical connection ability and student's creativity thinking. Furthermore, the results of the format selection in this study are adjusted to the 2013 curriculum. The format for RPP is adjusted with permendikbud. 22 year 2016 on the standard of basic and medium education process.

At the stage of the field, the results of the implementation plan of the learning process are shown in the test of the test of the global trial, the student activity sheet, the teacher book, the student, the test of learning result in the test of mathematical connection ability and creative thinking of the student, the guidance of census. All results at the design stage are referred to as the Preliminary Draft.

\section{Description steps of Design (Develop)}

At this stage an evaluation of the learning device has been designed (Initial Draft). Formative evaluation is done with 2 stages, namely: 1) one-on-one evaluation by experts and practitioners, and 2) field trials. The goal is to look at weaknesses and improve the tools that have been developed. The result of one-on-one evaluation by experts and practitioners in the form of content validity assessment shows that all learning devices meet valid criteria, with average content validity of $\mathrm{RPP}=4,009, \mathrm{LAS}=4,16, \mathrm{BPG}=4,009$, and $\mathrm{BS}=4,032$. All the items about connection capability test meet valid and reliable criteria with $r_{11}$ value $=0.913$ (very high category).

Field trials or trial I conducted to see the effectiveness of learning tools. In experiment I, the learning device has not fulfilled one of the effective criteria, so it must be revised to the learning device as well as re-done the trial II

\section{B. Description of the Test Result I}

Invalid criteria and learning tools based on validator judgments are met, since all validators perceive learning tools developed can be used with "little revisions" or "no revisions". The test result of mathematical connection ability in classical manner shows the total number of subjects who completed the score $\geq 2.67$ or in scale 100 value 56 with criteria $B$ reaching 20 students from 35 students or $57,14 \%$. So it does not meet the criteria of effectiveness based on the completeness of the expected learning outcomes. Furthermore, the effectiveness criteria based on student activity shows the overall percentage of student activity time has reached the percentage of ideal time set. The average percentage of student activity shows that the whole category of students' activity in Test $\mathrm{I}$ is still within the limits of ideal achievement percentage or tolerance 
interval Thus it can be concluded that the effective learning tool is viewed from the student activity in accordance with the percentage of ideal time. Then the criteria of effectiveness in terms of the achievement of teachers' ability to manage experimental learning 1 is in the good category. The instrument used to determine the achievement of the ability of teachers to manage this learning in the form of observation sheet the ability of teachers to manage learning. Observation done during the learning process that is as much as three times meeting at trial 1 . The last criterion of effectiveness is student response in following learning also fulfilled, because student which give positive response to component and implementation of learning reach $\geq 80 \%$ that is $89,81 \%$.

Overall learning tools developed meet the valid criteria, but not yet meet the criteria of effectiveness. This is because the mathematical aspects of mathematical connection ability of students in the classification has not been fulfilled. Thus the learning device must be revised and then conducted trial II.

\section{Description of the Test Result II}

The result of the students' mathematical connection test shows that the total number of subjects who completed the score $\geq 2.67$ or in scale 100 value 56 with criteria $B$ - reached 30 students from 35 students or $85.71 \%$. This shows the completeness criteria of mathematical connection ability of students fulfilled. the overall percentage of student activity time has reached the percentage of ideal time set. The average percentage of student activity shows that the whole category of students' activity in Test I is still within the ideal percentage of achievement of the ideal time or tolerance interval Thus it can be concluded that the effective learning tool is viewed from the student activity in accordance with the percentage of ideal time. Then the criteria of effectiveness in terms of achieving the ability of teachers to manage learning test 1 is in the good category. The last criterion of effectiveness is the student's response in following the learning is also fulfilled, because students who give positive response to the component and the implementation of learning reaches $\geq 80 \%$ is $92.04 \%$. So as a whole the instructional device-oriented problem-based learning model developed has met the valid criteria , practical and effective.

\section{Improved Student Mathematical Connection Ability}

Increased ability of mathematical connections increased from the average mathematical connection ability of students on posttest result of mathematical connection ability. The average of students' mathematical connection ability in trial I was 60,47 increased to 76 in trial II. Thus, an increase in the average score of the students' mathematical connection ability of 15.53. Then reviewed based on the N-Gain calculation of students' mathematical connection ability on trial I and trial II increased from 0.36 to 0.6 . The improvement of students' mathematical connections capability is also seen to increase in each indicator, among others, on inter-mathematical indicators of 0.93 , on interdisciplinary indicators of 0.78 , and 0.93 in daily life. This shows the ability of students' mathematical connections using learning tools developed based on realistic approaches improved from trial I to trial II.

\section{DISCUSSION}

The result of research indicates that the learning process based on realistic approach developed meet the criteria of valid and effective. After the valid and effective learning device is produced, the next goal is the application of learning tools developed able to improve students' mathematical connection ability.

Mathematical connection is one of the must-have capabilities to solve problems. According to NCTM (2000), mathematical connections are an important part that should be emphasized at every level of education [1]. Hafiz, et al (2017) also said the ability of mathematical connections is one of the mathematical forces that must be developed in the learning of mathematics in schools [2]. The ability of a mathematical connection is required to relate to various ideas or mathematical ideas accepted by students (Fauzi: 2015) [3] Siregar and Edy Surya (2017) also asserted, with the ability of mathematical connections, the ability of students in mathematics is expected to become more widespread. In addition, the ability to mathematical connection also can improve students' cognitive abilities such as recall, understand the application of environmental concepts and so on[4]. Without applying the concept of student experience, it would be difficult to remember certain material and remember too many separate concepts whereas mathematics is rich in principles. Mathematical connections are interrelationships between mathematical topics, interrelationships between mathematics and other disciplines, and mathematical relation to the real world or in everyday life. In addition, Coxford (1995) mathematical connection ability is the ability to connect conceptual and procedural knowledge, using mathematics on other topics, using mathematics in life activities, using inter-topic connections in mathematics [5].

The purpose of developing learning tools based on this realistic approach is to improve students' mathematical connection ability. The improvement students 'mathematical connection ability in review based on pre-test value and posttest of students' mathematical connection ability. Based on data analysis at description of research results, it is found that less than $50 \%$ of students who get the value of pre-test beyond the minimum threshold of mathematical connection capabilities. The ability of mathematical connection of students is low due to many things, among others, students are not accustomed in solving mathematical problems in the form of stories. Teachers are accustomed to giving problems that are not much different from the example. In addition, students learn by memorizing mathematical ideas instead of trying to figure out a completion idea, so that students are not accustomed to finding their own solution of a given problem. This resulted in students having difficulties in connecting existing mathematical ideas with everyday life, with other fields of science or even with newly taught mathematical ideas.

This is same with what is said (Hafiz, et al: 2017). The lack of mathematical connection ability when learning mathematics is caused by many things, one of which is because students are not able to connect the math ideas that have been taught and newly taught mathematical ideas [2]. 
This happens because students may often memorize mathematical ideas without trying to interpret ideas. According to Ausubel, learning is said to be meaningful if the information learned by learners is prepared in the appropriate cognitive structure so that learners have a strong memory and transfer learning is easily achieved. In addition, Fauzi (2015) also said students should be given the opportunity to see this connection in learning mathematics [3]. The main purpose of the mathematical connection is emphasized to students who play a major role in making connections. Therefore, to improve the ability of mathematical connections required learning tools that are able to connect mathematical ideas and provide meaningful learning. This is consistent with the realistic nature of the learning approach that emphasizes meaningful learning by using student contributions. So by using the contribution of students can improve students' mathematical connection ability. The results of this study also showed that students' mathematical connection ability increased. Improved mathematical connection capability seen from post-test result of mathematical connection ability obtained by student. Based on the n-gain calculation to see an improvement in students' mathematical connection capability, an increase of pre-test value to post-test with n-gaint value of 0.60 is interpreted into the n-gaint classification, in the "intermediate" interpretation. The improvement of students' mathematical connections capability is also evident in each indicator of connection capability, i.e an increase in mathematical connection indicators among mathematical topics, the connection between mathematical topics with other fields of science and the connection between mathematics and daily life. Improved mathematical connection capability occurs because the realistic based learning tools applied in the learning already meet the valid and effective criteria. With realistic learning tools, students become accustomed to solving non-routine problems (problems stories), the problems given familiar in the daily life of students, so that students do not feel bored in the learning process. With realistic-based learning tools students are also trained to solve problems by looking for solution ideas rather than examples. Students are directed to connect previously learned mathematical ideas to solve a given problem, so that learning takes place more meaningfully.

It is only natural that there is an increase in mathematical connection capability by using a realistic learning-based approach. This is because the students themselves find the concept and master the true findings, while the teacher's role is to guide the students by giving guided and the students are encouraged to think for themselves so they can find general principles based on the directions / questions given by the teacher and to how far Guided students depend on their abilities and the material being studied.

As noted earlier, the definition of mathematical connection ability is the ability to connect conceptual and procedural knowledge, using mathematics on other topics, using mathematics in life activities, knowing the connection between topics in mathematics. The ability of mathematical connection can be increased because the device applied to the students has fulfilled the criteria of validity and effectiveness of good learning tools, with good learning tools used and with the implementation of learning model based on realistic approach hence the ability of student mathematics connection is increasing. This is in line with Hedriana; etc (2014) said the ability of mathematical connections of students who were given learning by using contextual learning with manipulative mathematics increased compared to students who received conventional learning, this is because learning using contextual problems make students more easily understand the concept, by presenting the circumstances surrounding students make more students easy to understand math concepts [18]. This is in line with the research conducted by researchers using a realistic approach, realistic approach also starting from the problems so that it can improve the ability of mathematical connections. In addition, research conducted by Malasari; et al. (2017) which states improvement of mathematical connections of students in the experimental group obtained by the method of learning program Horay-based review reviews are better than control group students who get conventional learning [19]. this is because students who have learned the method of learning program Horay based learning reviews are used to finish temporary problems from conventional groups are not familiar with the problem. This fact is consistent with a realistic approach which is a learning centered on realistic issues. Furthermore this research is reinforced by Sirait (2017) who said the RME Approach that connected mathematical concepts with other concepts of science or everyday life, thus making learning more meaningful and mathematical connections of students to be better [10]. Saying a realistic context helps students acquire knowledge and skills because they have the opportunity to practice and learn the expected results. Learning by using a rrealistic approach can help students to see how mathematical ideas are interrelated. If a mathematical idea is associated with everyday experience, students will surely appreciate the usefulness of mathematics.

Math learning using realistic approach, can improve students' mathematical connection ability. This is because the learning using realistic approach is designed by presenting realistic problems close to the student's life, so that problem solving done by the students can run well and stimulate learners to rediscover the concept of learning through modeling activities. Besides that learning process using realistic approach using the contribution of the students makes students more active. Students also produce and provide meaningful learning experiences through the construction of interrelated concepts so as to enhance students' mathematical connection abilities.

\section{Conclusion}

Based on the results of the analysis and discussion in this study, presented several conclusions as follows: 1) The tools based learning approach based on realistic approach developed meet the valid criteria. The average value of the total validity of the RPP is 4,009 , the LAS is 4.16 , the teacher manual is worth 4,009, the student book is worth 4,034, and the test of mathematical connection ability and creative thinking has also been in valid category. 2) The increase of mathematical connection ability using learning tool based on realistic approach which has been developed seen in experiment I of $\mathrm{N}$-gain value is 0.36 while seen in trial II of $\mathrm{N}$-gain value is 
0.60 meaning it is in category "being ". 3) Learning tools based on realistic approach developed meet the effective criteria. Effective criteria are reviewed from: (a) mathematical connection completion of students in class with a minimum score of 56 (maximum score 100) with category B- has reached $85.71 \%$ in trial II; (b) student activity in all observed aspects is the ideal time tolerance set; (c) the achievement of teachers 'ability to manage learning in trial II is in very good category and (d) students' positive responses reach $92.04 \%$ of the components of the tools and learning activities.

\section{References}

[1] National Council of Teachers Of Mathematics (NCTM). 2000 Principles And Standards Schools Mathematics. Reston, VA: NCTM

[2] Hafiz, M, dkk. 2016. Concept Mapping Learning Strategy to Enhance Students' Mathematical Connection Ability. Mathematics, Science, and Computer Science Education (MSCEIS 2016) AIP Conf.

[3] Fauzi, Kms. Muhammad Amin . 2015. The Enhancement of Student's Mathematical Connection Ability and Self-Regulation Learning with Metacognitive Learning Approach in Junior High School. Research And Educations In Mathematics (ICREM7)

[4] Siregar, Nenta Dumalia dan Edy Surya. 2017. Analysis of Students' Junior High School Mathematical Connection Ability. International Journal of Sciences: Basic and Applied Research (IJSBAR). ISSN 23074531

[5] Coxford, A.F. 1995. "The Case for Connections", dalam Connecting Mathematics Across the Curriculum. Editor: House, P.A. dan Coxford, A.F. Reston, Virginia: NCTM

[6] Muchayat. 2011. Pengembangan Perangkat Pembelajaran Matematika dengan Strategi Ideal Problem Solving Bermuatan Pendidikan Karakter. Jurnal PP (Online), Vol 1, No. 2, (http://journal.unnes.ac.id/nju/index.php/jpppasca/ article/ download/1545/1721, diakses 2 November 2016).

[7] Sanjaya, W. 2010. Perencanaan dan Desain Sistem Pembelajaran. Jakarta: Kencana Prenada Media Group.

[8] Webb, David C, Henk van der Kooij dan Monica R. Geist. 2011. Design Research in the Netherlands: Introducing Logarithms Using Realistic Mathematics Education. Volume 2 Journal of Mathematics Education at
Teachers College Spring-Summer. Front Range Community College Westminster, Colorado

[9] Kwon, Oh Nam. 2002. Conceptualizing the Realistic Mathematics Education Approach in the Teaching and Learning of Ordinary Differential Equations. Journal of the Korea Society of Mathematical Education Series: Research in Mathematical Education Vol. 6, No. 2

[10] Sirait, Asril Rais dan Zainal Azis. 2017. The Realistic of Mathematic Educational Approach (RME) toward the Ability of the Mathematic Connection of Junior High School in Bukhari Muslim Medan. American Journal of Educational Research, 2017, Vol. 5, No. 9, 984-989

[11] Gordah, Eka Kasah. 2012. Upaya guru meningkatkan kemampuan koneksi dan pemecahan masalah matematis peserta didik melalui pendekatan open ended. Jurnal pendidikan dan kebudayaan, Vol.18, No.13.1

[12] Mandur, Kanisius, I Wayan Sadra, I Nengah Suparta. 2013. Kontribusi Kemampuan Koneksi, Kemampuan Representasi, Dan Disposisi Matematis Terhadap Prestasi Belajar Matematika Siswa Sma Swasta Di Kabupaten Manggarai. Jurnal Program Pascasarjana Universitas Pendidikan Ganesha Program Studi Matematika, Vol. 2

[13] Heuvel, Marja den Van, Panhuizen, M. 2003. The Didactical Use Of Models In Realistic Mathematics Education: An Example From A Longitudinal Trajectory On Percentage. Educational Studies In Mathematics 54: 9-35. Kluwer Academic Publishers. Printed In The Netherlands.

[14] Gravemeijer, K.P.E. 1994. Developing Realistic Mathematics Education. Utrecht: CD- Press, Freudenthal Institute

[15] Arikunto, S. 2009, Dasar - Dasar Evaluasi Pendidikan. Bumi Aksara, Jakarta.

[16] Sinaga, B. 2007. Pengembangan Model Pembelajaran Matematika Berdasarkan Masalah Berbasis Budaya Batak (PBM-B3). Disertasi Tidak diterbikan. Surabaya: Program Pascasarjana UNESA.

[17] Hake, R.R. 1999. Analizing Change/Gain Scores. American Educational Research Association's Division Measurement and Research Methodology

[18] Hendriana, Heris, dkk. 2014.MATHEMATICAL CONNECTION ABILITY AND SELF-CONFIDENCE (An experiment on Junior High School students through Contextual Teaching and learning with Mathematical Manipulative). International Journal of Education, Vol. 8 No. 1 December 2014.

[19] Malasari, P N, H, Nindiasari, dan Jaenudin. 2017. A Development of Mathematical Connecting Ability of Students in Junior High School through a Problem-Based Learning with Course Review Horay Method. Journal of Physics: Conf. Series 812 (2017) 012025. 